\title{
Comparison of Light Transmission Aggregometry and VerifyNow in Detecting Clopidogrel Resistance and Factors Affecting Clopidogrel Resistance in AMI-EST Patients Undergoing Percutaneous Coronary Intervention: A Cross-Sectional Study
}

\author{
Astuti Giantini ${ }^{1,2}$, Ina Susianti Timan ${ }^{1,2}$, Erlin Listiyaningsih ${ }^{3}$, Rahajuningsih Dharma ${ }^{1,2}$, \\ Rianto Setiabudy ${ }^{1}$, Idrus Alwi ${ }^{4}$, Lia Gardenia Partakusuma ${ }^{3}$, Nuri Dyah Indrasari ${ }^{1,2}$, \\ Alida Roswita Harahap ${ }^{1,5}$, Siskawati Suparmin ${ }^{1, *}$, Windy Sahar ${ }^{3}$, Renan Sukmawan ${ }^{3}$ \\ ${ }^{1}$ Faculty of Medicine, Universitas Indonesia, Jl. Salemba Raya No.6, Jakarta, Indonesia \\ ${ }^{2}$ Department of Clinical Pathology, Cipto Mangunkusumo National Central General Hospital, Jl. Pangeran Diponegoro No.71, Jakarta, Indonesia \\ ${ }^{3}$ Harapan Kita Heart and Vascular Hospital, Jl. Letjen S. Parman Kav.87, Jakarta, Indonesia \\ ${ }^{4}$ Department of Internal Medicine, Cardiology Division, Metropolitan Medical Centre (MMC) Hospital, Jl. H.R. Rasuna Said Kav. C-21, \\ Jakarta, Indonesia \\ ${ }^{5}$ Eijkman Institute, Jl. Pangeran Diponegoro No. 69, Jakarta, Indonesia \\ *Corresponding author. E-mail: siskawati.suparmin2@gmail.com
}

Received date: Dec 11, 2020; Revised date: Mar 2, 2021; Accepted date: Mar 8, 2021

\section{Abstract}

2 ACKGROUND: Light transmission aggregometry (LTA) and VerifyNow is commonly used to measure platelet responsiveness to clopidogrel. This study aimed to compare the results of LTA and VerifyNow P2Y12 assay for assessing the clopidogrel resistance in patients undergoing percutaneous coronary intervention and determine factors affecting clopidogrel resistance.

METHODS: The subjects were 119 patients who underwent percutaneous coronary intervention (PCI) and had given loading dose of $600 \mathrm{mg}$ clopidogrel. Blood samples were taken at 6 hour after clopidogrel loading dose. Platelet aggregation was measured by LTA and VerifyNow.
RESULTS: LTA and VerifyNow assay showed fair agreement with Kappa $=0.270, p=0.001$. The proportion of resistance to clopidogrel using VerifyNow was $21.8 \%$ and LTA was $47.1 \%$. Patients with diabetes melitus were more likely to develop clopidogrel resistance than patients without diabetes (OR of 7.67; 95\% CI: 1.87-31.50; $p=0.005$ ).

CONCLUSION: The ability of LTA and VerifyNow in detecting clopidogrel resistance were not comparable. Multivariate analysis results for VerifyNow shows diabetes mellitus as the greatest predictors of clopidogrel resistance.

KEYWORDS: agreement, clopidogrel resistance, LTA, predictor, VerifyNow

Indones Biomed J. 2021; 13(2): 163-9

\section{Introduction}

Acute coronary syndrome (ACS) consists of various clinical forms, ranging from unstable angina pectoris, acute non-ST elevation myocardial infarction and acute myocardial infarction with ST segment elevation (AMIEST). The most important intervention to improve the survival of AMI-EST patients is with a reperfusion strategy by primary percutaneous coronary intervention (PCI) within 12 hours of symptom onset.(1) Combination of aspirin, P2Y12 inhibitors and parenteral anticoagulants were standard therapy in AMI-EST patients to undergoing PCI.(2) Clopidogrel is an oral antiplatelet drug whose active metabolites inhibit platelet activation and aggregation irreversibly by inhibiting adenosine diphosphate (ADP) at P2Y12 receptor.(3)

The term of antiplatelet resistance is still a problem because it is used variously to indicate the failure of the agent to prevent the intended clinical condition or the 
failure of the agent to achieve a biochemical effect (pharmacokinetics and/or pharmacodynamics).(4) The presence of this resistance is a challenge and a problem in preventing restenosis post-PCI. Various mechanisms of antiplatelet resistance have been proposed including decreased bioavailability, genetic variation, increased platelet turnover, activation of platelets by alternative pathways, and individual variation.(5)

Individual variations can cause clopidogrel resistance, including diabetes mellitus (DM) or insulin resistance, hypercholesterolemia, hypertension, elderly patients, obesity, gender, and family history of coronary heart disease (CHD).(5) In DM patients, there may be a decrease in the clopidogrel response due to increased platelet aggregation due to increased platelet turnover and exposure to ADP, and increase in fibrinogen which can be directly interact with GpIIb/IIIa. In addition, an increase in thrombin, epinephrine which is a platelet agonist triggers platelet aggregation.(6) Increased shear stress in hypertension can lead to platelet reactivation so this is thought to be the cause of failure of the antiplatelet response.(7) Smoking is associated with an increased response to therapy with clopidogrel which known as smoker paradox.(6) The results of other studies regarding the relationship between individual factors and the occurrence of clopidogrel resistance were various.(8)

Several tests are available to measure platelet function and the effect of antiplatelets.(4) Light transmission aggregometry (LTA) is recognized as the gold standard for examining platelet function. However, LTA are highly operator-dependent and show little correlation with other available tests for antiplatelet resistance.(5) The LTA test requires a long time and is intensive sample preparation. Its reproducibility is also questionable.(9) The ideal test criteria include assessing that antiplatelet therapy should use physiologically relevant agonists to induce platelet aggregation, be easy to perform, provide fast results, correlate with clinical events, have high sensitivity, and are affordable. Currently, no technique meets these criteria.(5) The VerifyNow examination is one of the easiest platelet function point-of-care (POCT) systems to use and the results are quick compared to other platelet function tests.(9)

In this research, we studied comparison of aggregometer analyzers between LTA and VerifyNow to evaluate clopidogrel resistance, and to find out the factors affecting clopidogrel resistance in AMI-EST patients who undergoing PCI.

\section{Methods}

This was a cross-sectional study with AMI-EST patients who underwent PCI in the Harapan Kita National Heart Center Hospital, Jakarta, from September 2018 to April 2019 as the subjects. For the comparison of two method, we used different principle of measurement of 100-200 specimen as recommended in previous study. (10) To analyzed the relationship of the various variable with clopidogrel resistance, we use rule of thumbs for determining sample size. Since we use 11 variables then we need minumum 110 subjects for the study. In this study we got 119 subjects participated. This study have been approved by ethical committee of Faculty of Medicine Universitas Indonesia (Registry No. LB.02.01/VII/294/ KEP. 059/2018). The target population was AMI-EST patients who had undergone PCI and received clopidogrel therapy (loading dose $600 \mathrm{mg}$ ). Subjects were selected by consecutive sampling.

Blood samples were taken from the antecubital vein at 6 hour after the loading dose of $600 \mathrm{mg}$ clopidogrel, exclusion criteria if the platelet count was less than $150 \times 10^{9} / \mathrm{L}$ or more than $450 \times 10^{9} / \mathrm{L}$, receiving $\mathrm{P} 2 \mathrm{Y} 12$ adenosine diphosphate (ADP) receptor loading inhibitors in addition to clopidogrel. Not currently on Eptifibatide, Tirofiban $\mathrm{HCl}$, and Abciximab, and not willing to participate in this research.

\section{Platelet Function Tests}

LTA assesses platelet aggregation associated with the glycoprotein GPIIb/IIIa. This test is based on measuring the increase in light transmission via a platelet-rich plasma (PRP) sample after the addition of an exogenous agonist. During the examination, PRP becomes clearer after agonist addition due to platelet aggregate precipitation.(11) The clopidogrel resistances determined by using the LTA assay were defined as $\geq 59 \%$.(12)

The VerifyNow-P2Y12 Assay/VerifyNow P2Y12 Reaction Units (PRU) test is a rapid test that uses ADP to stimulate platelets in the presence of Prostaglandin E1 (PGE1) and which inhibits activation downstream of a second ADP receptor P2Y1 the assay system reagent is designed to specifically measure P2Y12-mediated platelet aggregation. Measurement of ADP-induced platelet activation is expressed as PRU. The clopidogrel resistances determined by using the VerifyNow assay were defined as PRU $\geq 208$. $(6,13)$ 


\section{Statistical Analysis}

The statistical test was performed using SPSS ver 20.0 program (IBM Coorporation, New York, USA). Agreement between the results obtained with the LTA and VerifyNow were established using quadratic weighted Kappa ( $\kappa)$ statistics. The relationship of demographic, risk factors, and laboratory results with clopidogrel resistance was determined by the Chi-Square test. In addition to conducting bivariate tests, the study also conducted multivariate tests with for determining variables affecting the clopidogrel resistance.

\section{Results}

Characteristics results of patients investigated are shown in Table 1. The proportion of clopidogrel resistance was $47.1 \%$ (56 of a total of 119 patients) with LTA and 21.8\% (26 of a total of 119 patients) using the VerifyNow. The LTA and VerifyNow compatibility tested with Kappa coefficient. A fair agreement was obtained with Kappa $=0.270, p=0.001$ with the distribution of data as shown in Table 2. The relationship of demographic, risk factors, and laboratory results with clopidogrel resistance can be seen in Table 3, Table 4, and Table 5. Three demographic factors, sex, age and BMI do not have a significant with clopidogrel resistance. The risk factor for that had a significant relationship with the clopidogrel resistance measured by VerifyNow was DM with $p=0.001$. There was no significant relationship between laboratory results and the clopidogrel resistance as shown in Table 5.

The final results of the multivarite logistic regression analysis presented in Table 6. From the multivariate analysis for VerifyNow, it turns out that the variable which has a significant relationship with clopidogrel resistance is diabetes mellitus. The final results of the multivarite logistic regression analysis examined by LTA did not obtain statistically significant predictors of the occurrence of clopidogrel resistance as presented in Table 7.

\section{Discussion}

In our study, we get more male than female subjects. Several studies found the dominance of subjects based on different sexes. This study is in line with previous studies which found that the number of male patients with AMI was greater than that of women.(14)

The age range of the subjects in this study was 24-76 years with mean 52.9 years which younger than the 2018
Table 1. Characteristics of research subjects $(n=119)$.

\begin{tabular}{|c|c|}
\hline Variable & n (\%) \\
\hline \multicolumn{2}{|c|}{ Basic Demographic } \\
\hline \multicolumn{2}{|l|}{ Sex } \\
\hline Male & $109(91.6)$ \\
\hline Female & $10(8.4)$ \\
\hline \multicolumn{2}{|l|}{ Age } \\
\hline$<60$ years & $84(70.6)$ \\
\hline$\geq 60$ years & $35(29.4)$ \\
\hline Mean \pm SD $(95 \% \mathrm{CI})$ & $52.9 \pm 10.1(24-76)$ \\
\hline \multicolumn{2}{|l|}{ BMI } \\
\hline$<25.00$ & $56(47.1)$ \\
\hline$\geq 25.00$ & $63(52.9)$ \\
\hline Mean \pm SD $(95 \%$ CI $)$ & $25.3 \pm 3.8(17.3-34.8)$ \\
\hline \multicolumn{2}{|c|}{ Risk Factors of ACS } \\
\hline \multicolumn{2}{|l|}{ Hypertension } \\
\hline No & $53(44.5)$ \\
\hline Yes & $66(55.5)$ \\
\hline \multicolumn{2}{|l|}{ Diabetes Melitus } \\
\hline No & $85(71.4)$ \\
\hline Yes & $34(28.6)$ \\
\hline \multicolumn{2}{|l|}{ Family history of ACS } \\
\hline No & $106(89.1)$ \\
\hline Yes & $13(10.9)$ \\
\hline \multicolumn{2}{|l|}{ Smoker } \\
\hline No & $35(29.4)$ \\
\hline Yes & $84(70.6)$ \\
\hline \multicolumn{2}{|c|}{ Laboratory Results } \\
\hline \multicolumn{2}{|l|}{ Total cholesterol } \\
\hline Normal (<200 mg/dL) & $82(78.1)$ \\
\hline $\operatorname{High}(\geq 200$ mg/dL) & $23(21.9)$ \\
\hline Mean \pm SD $(95 \%$ CI $)$ & $170.8 \pm 40.5(43-280)$ \\
\hline \multicolumn{2}{|l|}{ HDL-C } \\
\hline Normal ( $\leq 40$ mg/dL) & $39(37.1)$ \\
\hline High (>40 mg/dL) & $66(62.9)$ \\
\hline Mean \pm SD $(95 \%$ CI $)$ & $37.3 \pm 11.4(4-120)$ \\
\hline \multicolumn{2}{|l|}{ LDL-C } \\
\hline Normal (<160 mg/dL) & $83(79.0)$ \\
\hline $\operatorname{High}(\geq 160$ mg/dL) & $22(21.0)$ \\
\hline Mean \pm SD $(95 \%$ CI $)$ & $124.9 \pm 38.5(37-221)$ \\
\hline \multicolumn{2}{|l|}{ Triglyceride (mg/dL) } \\
\hline Normal (<200 mg/dL) & $86(86.0)$ \\
\hline $\operatorname{High}(>200 \mathrm{mg} / \mathrm{dL})$ & $14(14.0)$ \\
\hline Mean \pm SD $(95 \%$ CI $)$ & $139.7 \pm 61.0(57-382)$ \\
\hline \multicolumn{2}{|c|}{ Platelet Aggregation Examination } \\
\hline \multicolumn{2}{|l|}{ VerifyNow } \\
\hline$\leq 208 \mathrm{PRU}$ (sensitive) & $93(78.2 \%)$ \\
\hline >208PRU (resistant) & $26(21.8 \%)$ \\
\hline \multicolumn{2}{|c|}{ Light Transmission Aggregometry } \\
\hline$<59 \%$ (sensitive) & $63(52.9 \%)$ \\
\hline$\geq 59 \%$ (resistant) & $56(47.1 \%)$ \\
\hline
\end{tabular}

RISKESDAS data which shown the highest prevalence of coronary heart disease was found in the age group of more than 75 years.(15) Most of the subjects were in the 
Table 2. Agreement of LTA and Verifynow.

\begin{tabular}{llccc}
\hline & & \multicolumn{2}{c}{ Light Transmission Aggregometry } & \multirow{2}{*}{ Total } \\
\cline { 3 - 4 } & & Resistant & Non-resistant & \\
\hline \multirow{2}{*}{ VerifyNow } & Resistant & 20 & 6 & $\mathbf{2 6}$ \\
& Non-resistant & 36 & 57 & $\mathbf{9 3}$ \\
\hline \multirow{2}{*}{ Total } & & $\mathbf{5 6}$ & $\mathbf{6 3}$ & $\mathbf{1 1 9}$ \\
\hline
\end{tabular}

$<60$ years age group. The BMI variable may play role in this finding. From 119 subjects, 52.9\% had abnormal BMI. This result was in line with previous study, which found the largest number of patients with ACS were in the $<65$ years group and was overweight.(16)

This study aims to assess the compatibility of the VerifyNow with the LTA test. We found that the VerifyNow and LTA shows fair agreement. This result was similar to other study comparing VerifyNow and LTA which found fair agreement between these two methods with kappa 0.36 (95\% CI: 0.24-0.49).(17) Determination of clopidogrel resistance is very important in determining the success of therapy and reducing reinfarction due to clopidogrel resistance. The difference results of those two methods might resulted in difference serious clinical situation in patient with ACS. In most cases of disagreement, the LTA ranked patients in the normal platelet reactivity category whereas the VerifyNow measured it as platelet resistant, this also similar to previous study.(17) The proportion of clopidogrel resistance obtained from this study for VerifyNow was $21.8 \%$ and with LTA was $47.1 \%$, whereas a similar study from Indonesia conducted before obtained a proportion of clopidogrel resistance as much as $36 \%$.(16) There is agreement with several clinical studies conducted on patients China, Japan and Korea revealed that the frequency of clopidogrel resistance in Asians varies between $20-65 \% .(18,19)$

The proportion of patients with DM who experienced clopidogrel resistance was $47.1 \%$ compared to patients without DM $11.8 \%$. There was a significant relationship between DM and clopidogrel resistance $(p=0.001)$. Patients with comorbid DM were 6.7 times more likely to develop clopidogrel resistance when compared to patients without DM. The results of this study are consistent with another study which reported that the proportion of clopidogrel resistance in diabetic patients was higher than that of patients without diabetes, respectively $54.55 \%$ and $12.22 \%$ with a $p$-value $<0.001$.(20)

Insulin is a natural antagonist for platelet hyperactivity. Insulin causes decreased platelet response to various agonists including ADP. Insulin deficiency causes platelet reactivity through the substrate-dependent (IRS-dependent) insulin receptor mechanism which will increase intracellular calcium concentration and cause changes in platelet shape, thereby causing increased platelet degranulation and aggregation.(21)

The causes of clopidogrel resistance are still uncertain and very complex. Several factors behind the poor response to antiplatelet therapy in ACS patients, including drug

Table 3. Demographic factors affecting clopidogrel resistance using the VerifyNow and LTA.

\begin{tabular}{|c|c|c|c|c|c|c|c|c|}
\hline \multirow{3}{*}{$\begin{array}{c}\text { Basic Demographic } \\
\text { Variables }\end{array}$} & \multicolumn{4}{|c|}{ VerifyNow } & \multicolumn{4}{|c|}{ Light Transmission Aggregometry } \\
\hline & \multicolumn{2}{|c|}{ Clopidogrel Effect [n (\%)] } & \multirow[b]{2}{*}{$p$-value } & \multirow[b]{2}{*}{ OR $(95 \%$ CI $)$} & \multicolumn{2}{|c|}{ Clopidogrel effect [n (\%)] } & \multirow[b]{2}{*}{$p$-value } & \multirow[b]{2}{*}{ OR $(95 \% \mathrm{CI})$} \\
\hline & $\begin{array}{l}\text { Sensitive } \\
(n=93)\end{array}$ & $\begin{array}{c}\text { Resistant } \\
(n=26)\end{array}$ & & & $\begin{array}{c}\text { Sensitive } \\
(n=63)\end{array}$ & $\begin{array}{c}\text { Resistant } \\
(n=56)\end{array}$ & & \\
\hline \multicolumn{9}{|l|}{ Sex } \\
\hline Male $(n=109)$ & $86(78.9)$ & $23(21.1)$ & 0.454 & $1.602(0.394-6.687)$ & $59(54.1)$ & $50(45.9)$ & 0.513 & $1.77(0.473-6.626)$ \\
\hline Female $(\mathrm{n}=10)$ & $7(70)$ & $3(30)$ & & & $4(40)$ & $6(60)$ & & \\
\hline \multicolumn{9}{|l|}{ Age } \\
\hline$<60$ years $(\mathrm{n}=84)$ & $69(82.1)$ & $15(17.9)$ & 0.165 & $2.108(0.852-5.218)$ & $46(54.8)$ & $38(45.2)$ & 0.678 & $1.282(0.582-2.824)$ \\
\hline$\geq 60$ years $(\mathrm{n}=35)$ & $24(68.6)$ & $11(31.4)$ & & & $17(48.6)$ & $18(51.4)$ & & \\
\hline \multicolumn{9}{|l|}{ BMI } \\
\hline Normal $(n=56)$ & $41(73.2)$ & $15(26.8)$ & 0.314 & $0.578(0.240-1.393)$ & $31(55.4)$ & $25(44.6)$ & 0.754 & $1.201(0.583-2.473)$ \\
\hline Overweight $(n=63)$ & $52(82.5)$ & $11(17.5)$ & & & $32(50.8)$ & $31(49.2)$ & & \\
\hline
\end{tabular}


Table 4. Risk factors for clopidogrel resistance measured with VerifyNow and LTA.

\begin{tabular}{|c|c|c|c|c|c|c|c|c|}
\hline \multirow{3}{*}{$\begin{array}{c}\text { ACS Risk Factor } \\
\text { Variables }\end{array}$} & \multicolumn{4}{|c|}{ VerifyNow } & \multicolumn{4}{|c|}{ Light Transmission Aggregometry } \\
\hline & \multicolumn{2}{|c|}{ Clopidogrel Effect [n (\%)] } & \multirow[b]{2}{*}{$p$-value } & \multirow[b]{2}{*}{ OR $(95 \% \mathrm{CI})$} & \multicolumn{2}{|c|}{ Clopidogrel Effect [n (\%)] } & \multirow[b]{2}{*}{$p$-value } & \multirow[b]{2}{*}{ OR $(95 \% \mathrm{CI})$} \\
\hline & $\begin{array}{c}\text { Sensitive } \\
(\mathrm{n}=93)\end{array}$ & $\begin{array}{c}\text { Resistant } \\
(\mathrm{n}=26)\end{array}$ & & & $\begin{array}{c}\text { Sensitive } \\
(n=63)\end{array}$ & $\begin{array}{c}\text { Resistant } \\
(\mathrm{n}=56)\end{array}$ & & \\
\hline \multicolumn{9}{|l|}{ Hypertension } \\
\hline No $(n=53)$ & $40(75.5)$ & $13(24.5)$ & 0.681 & $0.755(0.316-1.804)$ & $30(56.6)$ & $23(43.4)$ & 0.594 & $0.304(0.631-2.697)$ \\
\hline Yes $(n=66)$ & $53(80.3)$ & $13(19.7)$ & & & $33(50)$ & $33(50)$ & & \\
\hline \multicolumn{9}{|l|}{ Diabetes Melitus } \\
\hline No $(n=85)$ & $75(88.2)$ & $10(11.8)$ & 0.001 & $6.697(2.597-17.114)$ & $48(56.5)$ & $37(48.5)$ & 0.309 & $1.643(0.737-3.662)$ \\
\hline Yes $(n=34)$ & $18(52.9)$ & $16(47.1)$ & & & $15(44.1)$ & $19(55.9)$ & & \\
\hline \multicolumn{9}{|l|}{ Family History of ACS } \\
\hline No $(n=106)$ & $83(78.3)$ & $23(21.7)$ & 1.000 & $1.083(0.275-4.262)$ & $59(55.7)$ & $47(44.3)$ & 0.161 & $2.824(0.819-9.746)$ \\
\hline Yes $(n=13)$ & $10(76.9)$ & $3(23.1)$ & & & $4(30.8)$ & $10(69.2)$ & & \\
\hline \multicolumn{9}{|l|}{ Smoker } \\
\hline No $(n=35)$ & $26(74.3)$ & $9(25.7)$ & 0.678 & $0.733(0.290-1.851)$ & $14(40)$ & $21(60)$ & 0.104 & $0.476(0.213-1.063)$ \\
\hline Yes $(n=84)$ & $67(79.8)$ & $17(20.2)$ & & & $49(58.3)$ & $35(41.7)$ & & \\
\hline
\end{tabular}

interactions, diabetes, genetic factors, and other factors such as inflammation and platelet activation due to plaque rupture. Drug and cigarette interactions through CYP450, clinical conditions such as diabetes, hypertension and genetic and epigenetic polymorphisms are thought to play an important role in the occurrence of clopidogrel resistance.(22)

The multivariate analysis for VerifyNow showed that the predictor associated with clopidogrel resistance was diabetes mellitus which had the greatest effect on clopidogrel resistance with an OR of 7.67 (95\% CI: 1.87$31.50)$.
The weakness of this study is that it is not able to assess the interactions between other risk factors. Based on the literature, meaningful interactions are obtained from genetic and epigenetic risk factors, but this research has not been carried out so that other examinations are needed related to these factors.

\section{Conclusion}

This study confirms a fair agreement of clopidogrel resistance; tested by LTA and VerifyNow examination.

Table 5. Relationship of laboratory results and clopidogrel resistance with the VerifyNow and LTA.

\begin{tabular}{|c|c|c|c|c|c|c|c|c|}
\hline \multirow{3}{*}{$\begin{array}{c}\text { Laboratory Results } \\
\text { Variables }\end{array}$} & \multicolumn{4}{|c|}{ VerifyNow } & \multicolumn{4}{|c|}{ Light Transmission Aggregometry } \\
\hline & \multicolumn{2}{|c|}{ Clopidogrel Effect [n (\%)] } & \multirow[b]{2}{*}{$p$-value } & \multirow[b]{2}{*}{ OR $(95 \%$ CI $)$} & \multicolumn{2}{|c|}{ Clopidogrel Effect [n (\%)] } & \multirow[b]{2}{*}{$p$-value } & \multirow[b]{2}{*}{ OR $(95 \%$ CI $)$} \\
\hline & $\begin{array}{c}\text { Sensitive } \\
(\mathrm{n}=93)\end{array}$ & $\begin{array}{c}\text { Resistant } \\
(\mathrm{n}=26)\end{array}$ & & & $\begin{array}{c}\text { Sensitive } \\
(n=63)\end{array}$ & $\begin{array}{c}\text { Resistant } \\
(\mathrm{n}=56)\end{array}$ & & \\
\hline \multicolumn{9}{|l|}{ Total cholesterol } \\
\hline Normal $(\mathrm{n}=82)$ & $65(79.3)$ & $17(20.7)$ & 0.485 & $1.673(0.593-4.715)$ & $42(51.2)$ & $40(48.8)$ & 0.959 & $1.145(0.454-2.891)$ \\
\hline $\operatorname{High}(n=23)$ & $16(69.6)$ & $7(30.4)$ & & & $11(47.8)$ & $12(52.2)$ & & \\
\hline \multicolumn{9}{|l|}{ HDL-C } \\
\hline Normal (n=39) & $31(79.5)$ & $8(20.5)$ & 0.842 & $1.24(0.475-3.238)$ & $19(48.7)$ & $20(51.3)$ & 0.94 & $0.894(0.405-1.974)$ \\
\hline $\operatorname{High}(\mathrm{n}=66)$ & $50(75.8)$ & $16(24.2)$ & & & $34(51.5)$ & $32(48.5)$ & & \\
\hline \multicolumn{9}{|l|}{ LDL-C } \\
\hline Normal $(\mathrm{n}=83)$ & $66(79.5)$ & $17(20.5)$ & 0.401 & $1.812(0.638-5.144)$ & $43(51.8)$ & $40(48.2)$ & 0.772 & $1.29(0.502-3.313)$ \\
\hline $\operatorname{High}(n=22)$ & $15(68.2)$ & $7(31.8)$ & & & $10(45.5)$ & $12(54.5)$ & & \\
\hline \multicolumn{9}{|l|}{ Triglyceride } \\
\hline Normal $(\mathrm{n}=86)$ & $67(77.9)$ & $19(22.1)$ & 0.314 & $1.959(0.586-6.544)$ & $44(51.2)$ & $42(48.8)$ & 1.000 & $1.048(0.339-3.242)$ \\
\hline High $(n=14)$ & $9(64.3)$ & $5(35.7)$ & & & $7(50)$ & $7(50)$ & & \\
\hline
\end{tabular}


Table 6. Multivariate logistic regression analysis with VerifyNow examination.

\begin{tabular}{lcccc}
\hline \multicolumn{1}{c}{ Predictor } & B & $\boldsymbol{p}$-value & Odd Ratio & $\mathbf{9 5 \%}$ CI \\
\hline Sex & -1.336 & 0.372 & 0.263 & $0.014-4.929$ \\
Age & 0.531 & 0.507 & 1.7 & $0.354-8.168$ \\
BMI & -0.386 & 0.579 & 0.68 & $0.174-2.651$ \\
Hypertension & -0.171 & 0.809 & 0.843 & $0.211-3.372$ \\
Diabetes Mellitus & 2.037 & $0.005^{*}$ & 7.668 & $1.867-31.50$ \\
Family History of ACS & -0.103 & 0.925 & 0.902 & $0.107-7.595$ \\
Smoker & -0.001 & 0.999 & 0.999 & $0.192-5.189$ \\
Total Cholesterol & -17.731 & 0.999 & 0 & - \\
HDL-C & 0.081 & 0.911 & 1.084 & $0.265-4.44$ \\
LDL-C & 19.204 & 0.999 & 218872791.4 & - \\
Triglycerides & 1.039 & 0.317 & 2.826 & $0.369-21.623$ \\
\hline
\end{tabular}

Table 7. Multivariate logistic regression analysis with LTA examination.

\begin{tabular}{lcccc}
\hline \multicolumn{1}{c}{ Predictor } & B & $\boldsymbol{p}$-value & Odd Ratio & $\mathbf{9 5 \%}$ CI \\
\hline Sex & -0.923 & 0.417 & 0.397 & $0.043-3.696$ \\
Age & 0.597 & 0.304 & 1.817 & $0.582-5.677$ \\
BMI & 0.36 & 0.486 & 1.434 & $0.521-3.949$ \\
Hypertension & -0.051 & 0.918 & 0.951 & $0.361-2.5$ \\
Diabetes Mellitus & 0.53 & 0.336 & 1.699 & $0.577-5.006$ \\
Family History of ACS & 1.081 & 0.243 & 2.947 & $0.481-18.078$ \\
Smoker & -0.033 & 0.958 & 0.968 & $0.291-3.216$ \\
Total Cholesterol & -0.334 & 0.803 & 0.716 & $0.052-9.83$ \\
HDL-C & -0.18 & 0.705 & 0.835 & $0.329-2.12$ \\
LDL-C & 0.723 & 0.598 & 2.061 & $0.14-30.302$ \\
Triglycerides & -0.371 & 0.62 & 0.69 & $0.159-2.989$ \\
\hline
\end{tabular}

Diabetes mellitus might be a significant predictor of clopidogrel resistance.

\section{Acknowledgements}

The research conducted by authors private fund, there was no research grant or sponsor to be disclosed.

\section{Authors Contribution}

$A G$ and EL were involved in the planning of the manuscript, supervised the work, and also analyzed the data. IST and RS were involved in planning and supervised the work. RD was involved in drafting the manuscript. RS, IA, LGP, NDI were involved in supervising the work. ARH were involved in drafting and reviewing manuscript. SS and WS were involved in literature searching, writing and data analysis. All authors discussed the results and commented on the manuscript.

\section{References}

1. Granger CB, Bates ER, Jollis JG, Antman EM, Nichol G, O’Connor RE, et al. Improving care of STEMI ini the United States 2008 to 2012: A report from the American Heart Association Mission: Lifeline program. J Am Heart Assoc. 2019; 8: e008096. doi: 10.1161/JAHA.118.008096. 
2. Ibanez B, James S, Agewall S, Antunes M, Bucciarelli-Ducci C, Bueno H, et al. 2017 ESC Guidelines for themanagement of acute myocardial infarction in patients presenting with ST-segment elevation. Eur Heart J. 2018; 39: 119-77.

3. Tran H, Mehta S, Eikelboom J. Clinical update on the therapeutic use of clopidogrel: treatment of acute ST-segment elevation myocardial infarction (STEMI). Vasc Health Risk Manag. 2006; 2: 379-87.

4. Wiviott S, Antman E. Clopidogrel resistance: A new chapter in fastmoving story. Circulation. 2004; 109: 3064-7.

5. Saraf S, Bensalha I, Gorog D. Antiplatelet resistance-does it exist and how to measure it? Clin Med Cardiol. 2009; 3: 77-91.

6. Yaseen I, Farhan H, Abbas H. Clopidogrel non-responsiveness in patients undergoing percutaneous coronary intervention using the VerifyNow test: frequency and predictors. Eur J Hosp Pharm. 2019; 26: 113-6.

7. Akturk I, Caglar F, Erturk M, Tuncer N, Yalcin A, Surgit O, et al. Hypertension as a risk factor for aspirin and clopidogrel resistance in patients with stable coronary artery disease. Appl Thromb. 2014; 20: 749-54

8. Koshy S, Salahuddin S, Karunakaran B, Nalakath S, Bhaskaran J, Haridas $\mathrm{P}$, et al. Aspirin and clopidogrel resistance using the cone and plate(let) analyser in Indian patients with coronary artery disease. Heart Asia. 2014; 6: 159-62.

9. Van Werkum J, Harmsze A, Elsenberg E, Bouman H, Ten Berg J, Hackeng $\mathrm{C}$, et al. The use of the Verify Now system to monitor antiplatelet therapy: A review of current evidence. Platelet. 2008; 19: 479-88.

10. Westgard JO [Internet]. Madison: Westgard QC; CC 2019.The Comparison of Methods Experiment [cited 2020 Aug 10]. Available from: https://www.westgard.com/lesson23.htm.

11. Helena Laboratories. Helena Platelet Aggregation Reagents, Cat. No. 5366, 5367, 5368, 5369. Beaumont; Helena Laboratories; n.y.

12. Gurbel P, Antonino M, Bliden K, DiChiara J, Suarez T, Singla A, et al. Platelet reactivity to adenosine diphosphate and long-term ischemic event occurrence following percutaneous coronary intervention: A potential antiplatelet therapeutic target. Platelets. 2008; 19: 595604.

13. Accriva Diagnostic. VerifyNow System: User Manual. California: Accriva Diagnostic; 2008.

14. Millet ERC, Peters SAE, Woodward M. Sex differences in risk factors for myocardial infarction: cohort study of UK Biobank participants. BMJ. 2018; 2018: 363. doi: 10.1136/bmj.k4247.

15. Badan Litbangkes Kementerian Kesehatan RI. Hasil Utama Riskesdas 2018. Jakarta: Badan Litbangkes Kementerian Kesehatan RI; 2019.

16. Rumenta D. Proporsi dan faktor yang mempengaruhi resistensi klopidogrel pada pasien sindrom koroner akut dan/atau post intervensi koroner perkutan di RS Jantung dan Pembuluh Darah Harapan Kita [Thesis] Jakarta: Universitas Indonesia; 2016.

17. Vries MJA, Bouman HJ, Olie RH, Veenstra LF, Zwaveling SI, Verhezen PWM, et al. Determinants of agreement between proposed therapeutic windows of platelet function tests in vulnerable patients. Eur Heart J Cardiovasc Pharmacother 2017; 3: 11-7.

18. Hasan MS, Basri HB, Hin LP, Stanslas J. Genetic polymorphisms and drug interactions leading to clopidogrel resistance: why the Asian population requires special attention. Int J Neurosci 2013; 123: 14354.

19. Jiang XL, Samant S, Lesko LJ, Schmidt S. Clinical pharmacokinetics and pharmacodynamics of clopidogrel. Clin Pharmacokinet 2015; 54: 147-66.

20. SuJun Feng, HuXiao Hui, LiCheng Yan. Risk factors for clopidogrel resistance in patients with ischemic cerebral infarction and the correlation with ABCB1 gene rs1045642 polymorphism. Exp Ther Med. 2015; 9: 267-71.

21. Randriamboavonjy V, Fileming I. Insulin, insulin resistance and platelet signaling in diabetes. Diabetes Care. 2009; 32: 528-31.

22. Vlachojannis GJ, Dimitropoulos G, Alexopoulos D. Clopidogrel Resistance: Current aspects and futute directions. HJC. 2010;52: 236-45. 